\title{
Pendampingan Aplikasi Chem Draw Untuk Meningkatkan Kemampuan Guru Dalam Menerapkan Bahan Ajar Student Centered Berbasis Informatika
}

\author{
Rina Hidayati Pratiwi ${ }^{1}$, Endang Sulistyaniningsih ${ }^{2}$, Fery Rahmawan ${ }^{2}$ \\ ${ }^{1}$ Program Studi Pendidikan Biologi, FMIPA, Universitas Indraprasta PGRI \\ ${ }^{2}$ Program Studi Teknik Informatika, FTIK, Universitas Indraprasta PGRI \\ 1rina.hp2012@gmail.com
}

\begin{abstract}
ABSTRAK
Kualitas karakter, kompetensi dan literasi dasar sehingga peserta didik cakap dalam memecahkan masalah, berpikir kritis, kolaborasi, dan berkomunikasi merupakan kecakapan yang dibutuhkan di abad 21. Studi ini bertujuan mengetahui hasil dari pelaksanaan pelatihan yang ditujukan untuk meningkatkan kualitas karakter, kompetensi dan literasi dasar profesionalisme guru di abad 21. Pelatihan tersebut ialah pendampingan peningkatan kemampuan guru dalam menerapkan bahan ajar Student Centered berbasis informatika melalui aplikasi Chem Draw. Pelatihan ditujukan ke guru MI dan SMP di Depok sebanyak lebih kurang 30 peserta. Dari pelaksanaan kegiatan pelatihan telah diperoleh data kemampuan guru dalam menerapkan bahan ajar Student Centered berbasis informatika melalui penggunaan aplikasi Chem Draw. Sebanyak 63,34\% peserta mendapatkan nilai di bawah 60, sedangkan yang mendapatkan nilai di atas 60 hanyalah sebanyak 36,66\%. Peserta yang mendapatkan nilai di atas 60 semuanya dari guru MI. Guru MI yang mendapatkan nilai di atas 60 lebih banyak dari guru kelas, dimana guru kelas adalah guru yang mengampu hampir semua mata pelajaran di kelas. Berdasarkan hasil pengisian angket tampak jelas bahwa rata-rata seluruh persentase tanggapan positif lebih besar dari 70\% dari jumlah total guru MI dan SMP. Dari uraian hasil dapat disimpulkan bahwa kegiatan pelatihan yang telah dilaksanakan berhasil memenuhi tujuannya.
\end{abstract}

Kata kunci: bahan ajar, Chem Draw, MI, SMP, Student Centered

\section{PENDAHULUAN}

Perkembangan dunia abad 21 ditandai dengan pemanfaatan teknologi informasi dan komunikasi dalam segala segi kehidupan, termasuk dalam proses pembelajaran. Dunia kerja menuntut perubahan kompetensi. Kemampuan berpikir kritis, memecahkan masalah, dan berkolaborasi menjadi kompetensi penting dalam memasuki kehidupan abad 21. Sekolah dituntut mampu menyiapkan siswa atau peserta didik untuk memasuki abad 21.

Kecakapan di abad 21 diantaranya adalah kualitas karakter, kompetensi dan literasi dasar sehingga peserta didik cakap dalam memecahkan masalah (problem solving), berpikir kritis (critical thinking), kolaborasi, dan berkomunikasi. Karakter adalah kualitas yang stabil dan khas yang dibangun di dalam kehidupan seorang individu yang menentukan responnya terlepas dari keadaan yang melingkupinya. Kualitas dari karakter yang akan menentukan respon seseorang dalam situasi apapun. Kompetensi yaitu sifat dasar yang dimiliki atau bagian kepribadian yang mendalam dan melekat kepada seseorang serta perilaku yang dapat diprediksi pada berbagai keadaan dan tugas pekerjaan sebagai dorongan untuk mempunyai prestasi dan keinginan berusaha agar melaksanakan tugas dengan efektif. Dengan kata lain, kompetensi adalah penguasaan terhadap seperangkat pengetahuan, ketrampilan, nilai nilai dan sikap yang mengarah kepada kinerja dan direfleksikan dalam kebiasaan berpikir dan bertindak sesuai dengan profesinya. Kompetensi diartikan sebagai kemampuan untuk melaksanakan atau melakukan suatu pekerjaan atau tugas yang dilandasi oleh keterampilan dan pengetahuan kerja yang dituntut oleh pekerjaan tersebut (Wibowo 2007).

Literasi Dasar, yaitu kemampuan untuk mendengarkan, berbicara, membaca, menulis, dan menghitung. Dalam literasi dasar, kemampuan untuk mendengarkan, berbicara, membaca, menulis, dan menghitung (counting) berkaitan dengan kemampuan analisis untuk memperhitungkan (calculating), mempersepsikan informasi (perceiving), mengomunikasikan, serta menggambarkan 
informasi (drawing) berdasar pemahaman dan pengambilan kesimpulan pribadi. Semua kecakapan literasi dasar bisa dimiliki oleh peserta didik apabila pendidik mampu mengembangkan rencana pembelajaran yang berisi kegiatan-kegiatan yang menantang peserta didik untuk berpikir kritis dalam memecahkan masalah. Kegiatan yang mendorong peserta didik untuk bekerjasama dan berkomunikasi harus tampak dalam setiap rencana pembelajaran yang dibuatnya.

Bahan ajar merupakan salah satu bagian penting dalam proses pembelajaran. Sebagaimana Mulyasa (2006: 96) mengemukakan bahwa bahan ajar merupakan salah satu bagian dari sumber ajar yang dapat diartikan sesuatu yang mengandung pesan pembelajaran, baik yang bersifat khusus maupun yang bersifat umum yang dapat dimanfaatkan untuk kepentingan pembelajaran. Pemanfaatan bahan ajar yang optimal perlu didasarkan pada kebermaknaan dan nilai tambah yang dapat diberikan kepada siswa melalui suatu pengalaman belajar di sekolah. Dengan demikian, bahan ajar adalah suatu bahan atau materi pelajaran yang disusun secara sistematis yang digunakan guru dan siswa dalam suatu pembelajaran untuk mencapai tujuan yang diharapkan.

Pembelajaran pada abad 21 hendaknya disesuaikan dengan kemajuan dan tuntutan zaman. Begitu juga halnya dengan kurikulum yang dikembangkan oleh sekolah dituntut untuk mengubah pendekatan pembelajaran yang berpusat pada guru atau pendidik (teacher centered learning) menjadi pendekatan pembelajaran yang berpusat pada peserta didik (student-centered learning). Hal ini sesuai dengan tuntutan dunia masa depan anak yang harus memiliki kecakapan berpikir dan belajar (thinking and learning skills).

Masih rendahnya kemampuan guru dalam menggunakan media yang berbasis informatika membuat perlunya diterapkan bahan ajar atau media pembelajaran yang berbasis informatika. Tujuan dari riset ini ialah mengetahui hasil dari pelaksanaan workshop atau pelatihan yang merupakan rangkaian kegiatan penelitian dan pengabdian masyarakat. Pelatihan yang bertujuan untuk meningkatkan kualitas karakter, kompetensi dan literasi dasar profesionalisme guru di abad 21 tersebut ialah pelatihan peningkatan kemampuan guru dalam menerapkan bahan ajar Student Centered berbasis informatika melalui aplikasi Chem Draw, yang ditujukan ke guru sebagai pelaku dalam hal penerapan bahan ajar sehingga proses dan hasil belajar dalam kegiatan belajar mengajar di sekolah semakin baik. Perangkat yang digunakan sebagai media informatika ialah komputer dengan software Chem Office karena software tersebut berisi berbagai aplikasi yang salah satunya adalah Chem Draw. Aplikasi Chem Draw berisi berbagai macam fitur yang dibutuhkan oleh guru dalam mengajar dan menyelesaikan tugas KBMnya. Diharapkan dengan diperkenalkannya aplikasi tersebut, akan memudahkan guru dalam menerapkan bahan ajar Student Centered berbasis informatika.

\section{METODE KEGIATAN \\ Kegiatan pelatihan bertujuan} melatihkan tujuh aspek yang diduga dapat mendukung pengembangan kemampuan merancang dan membuat bahan ajar Student Centered berbasis informatika, yaitu (1) menentukan tujuan kegiatan pembelajaran; (2) menentukan jenis bahan ajar yang sesuai dengan tujuan; (3) menentukan media pembelajaran yang sesuai dengan spesifikasi yang dibutuhkan; (4) merancang dan membuat bahan ajar; (5) merencanakan sendiri prosedur pembelajaran dan melaksanakannya; (6) menyusun lembar kerja siswa berbasis inkuiri; dan (7) merancang evaluasi kegiatan pembelajaran.

Metode pelaksanaan pelatihan dalam meningkatkan aspek-aspek kemampuan tersebut dikembangkan melalui lima tahap pelatihan, yaitu penyampaian dan penjelasan materi digunakan untuk menyampaikan materi motivasi dan ChemOffice yang sebelumnya belum dikenal oleh peserta, pre-test dan posttest digunakan sebagai instrument untuk mengukur kemampuan peserta pelatihan terhadap materi yang akan dipelajari, tanya jawab dilaksanakan saat penyampaian materi diberikan atau selama pelaksanaan kegiatan, praktik langsung menggunakan aplikasi dari software ChemOffice yaitu Chem Draw, dan terakhir evaluasi kegiatan yang dilaksanakan satu minggu setelah pelaksanaan pelatihan di pertemuan terakhir.

\section{Parameter Keberhasilan Program}

Program ini dianggap berhasil apabila tim berhasil melaksanakan pelatihan peningkatan kemampuan guru dalam 
menerapkan bahan ajar Student Centered berbasis informatika bagi guru sekolah MI dan SMP.

\section{Rencana Pengembangan Keberlanjutan Program}

Untuk menjaga keberlanjutan program, dalam jangka panjang akan dikembangkan program pelatihan lebih lanjut yang melibatkan peserta lebih banyak dan diharapkan didanai Dinas Pendidikan di Kota Depok secara mandiri.

\section{Persiapan Pelaksanaan Pelatihan}

Persiapan pelaksanaan pelatihan yang dilakukan untuk memperlancar jalannya kegiatan pelatihan yaitu mempersiapkan segala keperluan yang dibutuhkan, diantaranya:

1. Mempersiapkan referensi, piranti kegiatan hardware dan software dengan tujuan memperoleh bahan/ referensi, hardware dan software terkait pelatihan bahan ajar Student Centered berbasis informatika melalui aplikasi Chem Draw

2. Menyusun materi pelatihan terkait dengan penerapan bahan ajar Student Centered berbasis informatika melalui aplikasi Chem Draw

3. Menyusun instrumen yang diperlukan untuk workshop pelatihan

4. Menyusun soal dan lembar kerja yang bisa dikerjakan sebagai tugas bagi guru-guru peserta pelatihan

5. Melakukan simulasi internal yang bertujuan untuk melakukan kegiatan simulasi sebelum pelaksanaan workshop pelatihan agar lebih termonitor kebutuhannya sebelum pelaksanaan workshop pelatihan

6. Mempersiapkan perangkat pelatihan secara lengkap dan pembagian tugas selama pelatihan

\section{Hasil Persiapan Pelatihan}

1. Modul "Pelatihan peningkatan kemampuan guru dalam menerapkan bahan ajar Student Centered berbasis informatika bagi guru sekolah MI dan SMP di Depok".

2. Software Chem Office dan aplikasi Chem Draw yang bisa diinstall ke komputer peserta pelatihan

3. Soal dan lembar kerja yang bisa dikerjakan oleh guru peserta pelatihan

4. Angket respon peserta terhadap pelaksanaan pelatihan

\section{Pelaksanaan Kegiatan Pelatihan}

Berdasarkan hasil koordinasi dengan Kepala Yayasan Al Falah Satu, pelatihan telah kami laksanakan pada hari Senin hingga Rabu, tanggal 7 sampai dengan 9 Mei 2018 di MI dan SMP Al Falah Satu Depok, diikuti oleh 30 peserta yang merupakan guru MI dan SMP di Depok.

Dari pelaksanaan kegiatan "Pelatihan peningkatan kemampuan guru dalam menerapkan bahan ajar Student Centered berbasis informatika" telah diperoleh data kemampuan guru dalam menerapkan bahan ajar Student Centered berbasis informatika melalui penggunaan aplikasi Chem Draw.

\section{HASIL \& PEMBAHASAN}

\section{Kegiatan Penyajian Materi}

Kegiatan pelatihan dilaksanakan di salah satu sekolah di Depok yaitu di MI dan SMP swasta Al Falah Satu dengan tujuan untuk meningkatkan kualitas, kreativitas, keterampilan dan inovasi dalam melaksanakan pembelajaran. Pelatihan dilaksanakan selama 3 hari dengan durasi masing-masing sekitar 5 jam efektif untuk melaksanakan pelatihan.

Pelaksanaan kegiatan penyajian materi yang telah dilaksanakan bertujuan melakukan pembinaan guru MI dan SMP di Depok tentang penerapan bahan ajar Student Centered berbasis informatika melalui penggunaan aplikasi Chem Draw. Secara umum, kegiatan penyajian materi berlangsung sangat baik. Peserta dengan antusias dan bersungguhsungguh mengikuti sesi demi sesi setiap materi pelatihan yang disampaikan oleh nara sumber, baik materi yang terkait dengan motivasi maupun materi yang terkait dengan media pengajaran. Demikian pula kegiatan diskusi berlangsung sangat baik. Respon peserta maupun tanggapan dari nara sumber berlangsung dengan baik. Banyaknya pertanyaan yang muncul dari peserta menunjukkan adanya respon positif dari peserta terhadap materi pelatihan, selain itu juga menunjukkan rasa ingin tahu yang besar dari peserta terhadap hal-hal baru yang ingin diketahui karena penggunaan aplikasi Chem Draw sebagai bahan ajar ini masih merupakan hal yang baru bagi peserta pelatihan.

Pemanfaatan aplikasi Chem Draw yang merupakan salah satu aplikasi dari software Chem Office sebagai media untuk menerapkan bahan ajar Student Centered berbasis informatika dilatar belakangi kondisi 
obyektif tentang fenomena guru yang masih menggunakan cara mengajar yang konvensional dengan media pembelajaran yang sederhana. Penerapan bahan ajar Student Centered begitu penting diterapkan untuk meningkatkan kualitas karakter, kompetensi, dan literasi dasar. Pentingnya bahan ajar yang berbasis informatika karena seiring dengan perkembangan teknologi yang semakin maju, maka guru dituntut harus memiliki skill di bidang informatika yang salah satunya digunakan untuk media pembelajaran atau menyelesaikan tugas-tugas guru di KBM sehari-harinya. Karena motivasi guru untuk melakukan inovasi dalam penyampaian materi ke siswa juga masih kurang. Padahal guru merupakan subyek dari suatu KBM dan siswa merupakan obyek dari suatu KBM. Seorang siswa baru akan memahami suatu materi dalam pelajaran atau bidang ilmu jika disampaikan dengan cara yang menarik dan terfokus.

Dari kegiatan pelatihan yang telah dilaksanakan, dapat diketahui bahwa pengetahuan awal peserta tentang bahan ajar student centered berbasis informatika dan penggunaan aplikasi Chem Draw sebagai bahan ajar masih kurang. Namun, berdasarkan hasil angket respon peserta pelatihan yang ditunjukkan pada Tabel 2, memperkuat bahwa setelah diberikan pelatihan, tingkat pemahaman peserta pelatihan menunjukkan hasil yang baik.

Bagi para guru, kendala yang sering muncul dalam memberikan bahan ajar ke siswa adalah kesulitan membuat atau mencari media pembelajaran yang tepat untuk diberikan ke siswa sehingga untuk menghemat waktu, akhirnya bahan ajar yang diberikan dengan cara metode konvensional atau ceramah. Selain itu adanya kesulitan guru dalam menggunakan sesuatu yang berbasis informatika, diantaranya cara mengoperasikan dan bahasa program. Banyaknya aplikasi di komputer yang menuntut kemampuan tinggi untuk mengoperasikannya dan bahasa program yang sulit dimengerti menjadi salah satu kendala sehingga guru enggan untuk menggunakan dan menerapkannya dalam pembelajaran. Kondisi tersebut membuat perlu adanya aplikasi yang ringan, murah, dan mudah untuk digunakan guru dalam berinovasi di KBM.

Kegiatan pelatihan ini telah dilaksanakan menggunakan tiga metode, yaitu presentasi, demonstrasi, dan praktik. Metode presentasi digunakan untuk menyampaikan materi terkait motivasi dan bahan ajar student centered berbasis informatika. Metode demonstrasi digunakan untuk menjelaskan cara mengoperasikan aplikasi Chem Draw. Metode praktik digunakan untuk mengajarkan guru membuat bahan ajar student centered berbasis informatika dan mengarahkan guru untuk mengerjakan tugas-tugas yang terkait dengan KBM dengan menggunakan aplikasi Chem Draw.

\section{Evaluasi Peserta terhadap Kegiatan Pelatihan}

Sebelum kegiatan dimulai, peserta guru diminta untuk mengisi soal pretest terlebih dahulu. Soal pretest ini diberikan dalam rangka untuk mengetahui kemampuan awal atau pemahaman peserta terkait komputer, software Chem Office dan aplikasi Chem Draw. Pretest ini juga bertujuan untuk mengetahui seberapa besar motivasi guru untuk melakukan inovasi dalam penyampaian bahan ajar ke siswa saat KBM.

Berdasarkan hasil pretest yang telah diisi oleh lebih kurang 30 peserta guru dari MI dan SMP Al Falah Satu, maka diperoleh data sebagai berikut:

1. Sebanyak $63,34 \%$ peserta mendapatkan nilai di bawah 60, sedangkan yang mendapatkan nilai di atas 60 hanyalah sebanyak $36,66 \%$

2. Peserta yang mendapatkan nilai di atas 60 semuanya dari guru MI

3. Guru MI yang mendapatkan nilai di atas 60 lebih banyak dari guru kelas, dimana guru kelas adalah guru yang mengampu hampir semua mata pelajaran di kelas

Berdasarkan data di atas, maka dapat disimpulkan bahwa peserta yang memahami bahan ajar student centered berbasis informatika khususnya yang terkait aplikasi Chem Draw masih sedikit pada saat sebelum diberikan pelatihan. Setelah pengisian pretest selesai, kegiatan dilanjutkan dengan memberikan pemahaman awal tentang motivasi. Hal tersebut diberikan dengan tujuan untuk menumbuhkan motivasi dan semangat bagi para peserta guru sebelum diperkenalkan aplikasi komputer untuk media bahan ajar student centered berbasis informatika agar mau belajar dan menerapkan aplikasi yang akan diberikan. 
Selanjutnya guru diajak untuk mempraktikkan langsung cara menggunakan aplikasi Chem Draw sebagai media bahan ajar student centered berbasis informatika. Kegiatan ini diawali dengan simulasi yang dilakukan oleh pemateri atau nara sumber. Peserta mengikuti setiap instruksi yang diberikan oleh pemateri dengan panduan dari modul yang diberikan ke masing-masing peserta pelatihan.

Setelah peserta dirasa mampu menggunakan aplikasi Chem Draw, peserta diminta menyelesaikan beberapa soal yang ada di modul. Peserta juga diminta membuat inovasi pembelajaran dan menyelesaikan contoh tugas sesuai dengan masing-masing bidang studi yang diajarkan dengan menggunakan aplikasi Chem Draw. Setelah kegiatan tersebut selesai, panitia mengecek dan memberikan saran terhadap hasil pekerjaan yang sudah dibuat oleh peserta pelatihan. Panitia juga memberikan kesempatan ke peserta yang ingin bertanya dan diskusi terkait software Chem Office secara umum dan khususnya aplikasi Chem Draw. Banyak diskusi dan tanya jawab yang dilontarkan antara peserta dengan pemateri atau nara sumber. Dari hasil observasi selama pelatihan menunjukkan bahwa secara umum guru mudah memahami materi yang diberikan oleh nara sumber dan tidak mengalami kesulitan untuk menggunakan aplikasi Chem Draw pada pelatihan tersebut.

Kondisi sebelum dan setelah kegiatan pelatihan terindikasi tampak berbeda dalam cara pembuatan gambar dan penyelesaian tugas guru (Tabel 1). Setelah diberikan pelatihan, para guru lebih cepat dalam menyelesaikan tugasnya dibandingkan sebelum diberikan pelatihan. Hasil tugas yang diselesaikan tampak lebih bervariasi serta dapat menunjukkan tingkat inovasi dan kreativitas para guru.

\section{Respon Peserta terhadap Kegiatan Pelatihan \\ Setelah kegiatan "Pelatihan} peningkatan kemampuan guru dalam menerapkan bahan ajar Student Centered berbasis informatika melalui aplikasi Chem Draw" bagi guru MI dan SMP di daerah Depok ini seluruh peserta diminta untuk menjawab Instrumen Angket Respon Pelatihan untuk mengetahui pemahaman peserta terhadap materi pelatihan dan pendapatnya terhadap pelatihan yang telah dilaksanakan. Instrumen angket berisikan 11 pertanyaan sebagaimana tertera pada Tabel 2.

Tabel 1. Kondisi Sebelum dan Sesudah Pelaksanaan Pelatihan

\begin{tabular}{|c|c|c|}
\hline Uraian & Kondisi sebelum kegiatan & Kondisi setelah kegiatan \\
\hline $\begin{array}{l}\text { Pembuatan gambar } \\
\text { bidang datar }\end{array}$ & $\begin{array}{l}\text { Guru membuat gambar bidang datar } \\
\text { secara manual } \\
\text { menggunakan fitur yang ada di } \\
\text { Ms.Word }\end{array}$ & $\begin{array}{l}\text { Guru mampu membuat gambar bidang datar } \\
\text { dengan menggunakan fitur yang ada di } \\
\text { aplikasi Chem Draw }\end{array}$ \\
\hline $\begin{array}{l}\text { Pembuatan gambar } \\
\text { senyawa kimia }\end{array}$ & $\begin{array}{l}\text { Guru membuat gambar bidang datar } \\
\text { secara manual }\end{array}$ & $\begin{array}{l}\text { Guru mampu membuat gambar bidang datar } \\
\text { dengan menggunakan fitur yang ada di } \\
\text { aplikasi Chem Draw }\end{array}$ \\
\hline $\begin{array}{l}\text { Pembuatan } \\
\text { tugas guru }\end{array}$ & $\begin{array}{l}\text { Guru masih membuat tugasnya } \\
\text { secara manual }\end{array} \begin{array}{l}\text { dengan } \\
\text { menggunakan fitur yang ada di } \\
\text { Ms.Word }\end{array}$ & $\begin{array}{l}\text { Guru sudah bisa membuat tugasnya dengan } \\
\text { menggunakan fitur yang ada di aplikasi } \\
\text { Chem Draw }\end{array}$ \\
\hline $\begin{array}{l}\text { Variasi gambar } \\
\text { bidang yang dibuat }\end{array}$ & $\begin{array}{l}\text { Satu lembar kerja hanya dibuat } \\
\text { sedikit variasi gambar }\end{array}$ & $\begin{array}{l}\text { Satu lembar kerja sangat banyak dibuat } \\
\text { berbagai variasi gambar bidang }\end{array}$ \\
\hline $\begin{array}{l}\text { Efisiensi } \\
\text { keefektifan }\end{array}$ & $\begin{array}{l}\text { Guru lama dalam menyelesaikan } \\
\text { tugas yang diberikan }\end{array}$ & $\begin{array}{l}\text { Guru lebih cepat dalam menyelesaikan tugas } \\
\text { yang diberikan }\end{array}$ \\
\hline $\begin{array}{l}\text { Pemanfaatan } \\
\text { teknologi }\end{array}$ & $\begin{array}{l}\text { Guru menyelesaikan tugas yang } \\
\text { terkait dengan KBM dengan } \\
\text { menggunakan aplikasi Ms. Word }\end{array}$ & $\begin{array}{l}\text { Guru menyelesaikan tugas yang terkait } \\
\text { dengan KBM dengan menggunakan aplikasi } \\
\text { Chem Draw }\end{array}$ \\
\hline
\end{tabular}


Pada Tabel 2 menunjukkan persentase tanggapan positif berdasarkan hasil pengisian angket yang dilakukan oleh seluruh peserta dengan jumlah total yang mengisi 18 orang guru MI dan SMP. Berdasarkan pemaparan hasil angket pada Tabel 2 tampak dengan jelas bahwa rata-rata seluruh persentase tanggapan positif lebih besar dari $70 \%$ dari jumlah total guru MI dan SMP.

Diantara seluruh pertanyaan angket pertanyaan nomor 6 memperoleh tanggapan positif paling kecil yaitu $33,33 \%$, hal ini dikarenakan faktor lamanya waktu pelatihan dalam satu harinya ialah hanya sebanyak 5 jam. Peserta pelatihan merasa kurang dengan waktu yang disediakan oleh panitia sehingga peserta pelatihan menginginkan penambahan waktu pelatihan khususnya untuk kegiatan praktek. Sebenarnya hal tersebut senada dengan faktor penghambat dalam melakukan abdimas pada umumnya, yaitu rencana waktu pelaksanaan kegiatan abdimas yang harus disesuaikan dengan waktu kosongnya guru (Nurhaedah 2012), artinya saat guru tidak ada jam mengajar baru bisa dilakukan kegiatan abdimas. Faktor lainnya yang membuat guru merasa kurang dengan waktu yang disediakan panitia ialah karena belum familiarnya guru dengan materi yang disampaikan di pelatihan.

Tabel 2. Hasil Respon Peserta Terhadap Kegiatan Pelatihan

\begin{tabular}{|c|c|c|}
\hline No & Pertanyaan Angket & $\begin{array}{c}\text { Persentase } \\
\text { Tanggapan Positif }\end{array}$ \\
\hline 1 & $\begin{array}{l}\text { Berkaitan dengan materi workshop, materi yang diberikan } \\
\text { merupakan hal yang baru }\end{array}$ & 100 \\
\hline 2 & $\begin{array}{l}\text { Materi yang diberikan dapat membantu saya untuk memberikan } \\
\text { bahan ajar ke siswa }\end{array}$ & 83,33 \\
\hline 3 & $\begin{array}{l}\text { Modul dan lembar kerja yang diberikan pada saat workshop dapat } \\
\text { membantu saya merancang metode pembelajaran }\end{array}$ & 77,78 \\
\hline 4 & $\begin{array}{l}\text { Dengan workshop ini saya merasa memperoleh gambaran yang } \\
\text { kongkrit bagaimana cara menyampaikan materi ke siswa }\end{array}$ & 77,78 \\
\hline 5 & Menurut saya, pelaksanaan workshop ini cukup efektif & 72,22 \\
\hline 6 & Menurut saya, alokasi waktu workshop sangat sesuai & 33,33 \\
\hline 7 & $\begin{array}{l}\text { Pengetahuan/ keterampilan yang saya peroleh dari kegiatan ini } \\
\text { dapat saya manfaatkan dalam memberikan materi pembelajaran di } \\
\text { kelas }\end{array}$ & 83,33 \\
\hline 8 & $\begin{array}{l}\text { Pengetahuan/ keterampilan yang saya peroleh dari kegiatan ini } \\
\text { dapat saya manfaatkan dalam menyelesaikan tugas-tugas guru } \\
\text { (seperti pembuatan soal, pembuatan karya tulis, dsb) }\end{array}$ & 77,78 \\
\hline 9 & $\begin{array}{l}\text { Pelatihan ini menyediakan sumber dan media belajar yang kaya/ } \\
\text { beragam }\end{array}$ & 72,22 \\
\hline 10 & $\begin{array}{l}\text { Pembelajaran dari pelatihan ini memacu saya untuk belajar lebih } \\
\text { dalam lagi }\end{array}$ & 94,12 \\
\hline 11 & Secara umum, saya merasa puas mengikuti kegiatan pelatihan ini & 88,89 \\
\hline & Rata-Rata & 78,17 \\
\hline
\end{tabular}

Tanggapan positif maksimal $100 \%$ diberikan pada pertanyaan pada nomor 1 . Hal tersebut menunjukkan bahwa ilmu yang diberikan pada pelatihan ini merupakan ilmu yang baru bagi peserta dimana peserta merasa belum pernah mendapatkan ilmu tentang aplikasi Chem Draw sebelumnya dan juga belum pernah mempelajarinya. Walaupun demikian, berdasarkan tanggapan positif peserta, setelah peserta memperoleh ilmu khususnya tentang aplikasi Chem Draw dari pelatihan ini, peserta merasakan manfaatnya karena dapat membantu mereka untuk memberikan bahan ajar ke siswa dan dapat dimanfaatkan pula oleh peserta dalam memberikan materi pembelajaran di kelas. Adanya pemberian materi terkait motivasi juga berhasil memberikan dampak besar bagi peserta. Hal tersebut terlihat dari respon positif peserta yang terlihat dari hasil angket di Tabel 2, dimana secara umum peserta pelatihan menyampaikan tingkat kepuasan yang tinggi atas materi dan pendampingan pelatihan yang telah dilaksanakan oleh Tim Abdimas dengan 
hasil yang cukup dapat dipahami karena dari pelatihan tersebut memacu setiap peserta untuk belajar lebih dalam lagi.

Tanggapan positif peserta selain dari hasil pengisian angket juga sangat baik. Hal tersebut terlihat dari hasil kesan dan pesan yang disampaikan oleh peserta pelatihan, diantaranya para peserta merasa ilmu yang telah diterima saat pelatihan merupakan ilmu baru karena baru pertama kali diperoleh namun sangat membantu untuk mengembangkan materi pembelajaran, begitu memotivasi untuk lebih mengembangkan pembelajaran menjadi mudah, sehingga peserta menginginkan supaya pelatihan yang serupa tersebut tetap berlanjut dan pemateri tetap konsisten memberikan yang terbaik untuk sekolah serta untuk dunia pendidikan. Peserta juga menginginkan diadakannya pelatihan kembali untuk materi baru yang lain dengan ide pembelajaran yang lebih inovatif.

Ada pula peserta yang menyatakan bahwa setelah mengikuti pelatihan dapat menambah ilmu tentang aplikasi komputer dan informasi-informasi baru, wawasan dalam mengaplikasikan bahan pengajaran secara mudah, dan pengetahuan tentang pendidikan. Dari pernyataan tersebut terlihat bahwa adanya keinginan peserta untuk memanfaatkan hasil pelatihan dalam kegiatan pembelajaran di sekolah karena untuk mencapai tujuan pembelajaran, media sangat diperlukan untuk mempermudah membawa pesan-pesan atau informasi yang bertujuan memperjelas pembelajaran (Arysad 2003).

Bahan ajar Student Centered berbasis informatika melalui aplikasi Chem Draw tersebut termasuk salah satu contoh dari media literasi, artinya peserta dapat mengetahui bagaimana membuat media yang sifatnya by design (membuat sendiri) dengan aplikasiaplikasi dalam Chem Draw yang merupakan bahan ajar berbasis informatika. Berdasarkan hasil analisis kegiatan abdimas penggunaan media literasi dalam kegiatan pembelajaran materi di tingkatan SD memang lebih fleksibel. Selain itu berdasarkan hasil kegiatan beberapa abdimas, penggunaan media literasi tersebut memiliki keunggulan dibandingkan kegiatan pembelajaran itu sendiri yang tanpa menggunakan media literasi (Gunansyah et al. 2018). Berikut merupakan dokumentasi pelaksanaan kegiatan yang telah diuraikan di atas.
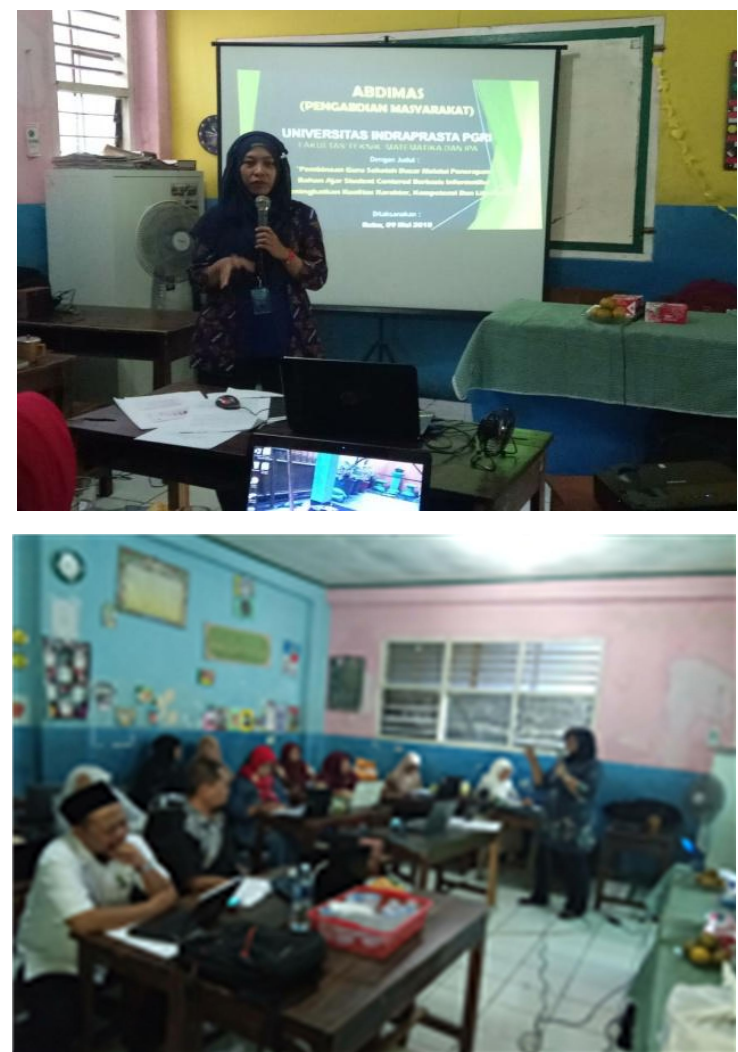

Gambar 1. Pelaksanaan Pelatihan Pada Saat Pemberian Materi
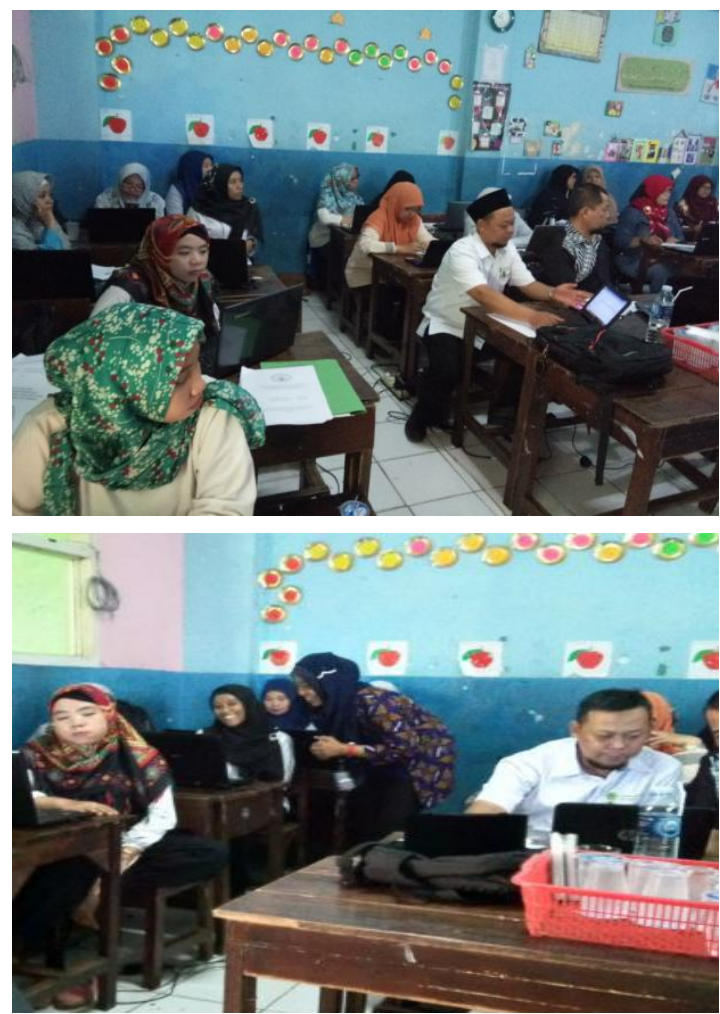

Gambar 2. Pelaksanaan Pelatihan Pada Saat Praktik 


\section{KESIMPULAN \& SARAN}

Berdasarkan proses evaluasi dan

analisis data hasil kegiatan "Pelatihan peningkatan kemampuan guru dalam menerapkan bahan ajar Student Centered berbasis informatika melalui aplikasi Chem Draw" bagi guru MI dan SMP dapat disimpulkan bahwa:

1) Ilmu yang diberikan pada pelatihan ini merupakan ilmu yang baru bagi peserta dimana peserta merasa belum pernah mendapatkan ilmu tentang penerapan bahan ajar Student Centered berbasis informatika melalui aplikasi Chem Draw sebelumnya dan juga belum pernah mempelajarinya

2) Peserta begitu semangat dan antusias dalam mengikuti pelatihan, sehingga waktu yang disediakan oleh panitia terasa kurang menurut peserta. Peserta pelatihan menginginkan waktu pelatihan ditambah untuk prakteknya.

3) Aplikasi Chem Draw memiliki beberapa fitur yang dapat digunakan oleh guru untuk berkreasi mencari inovasi baru dalam penerapan bahan ajar Student Centered berbasis informatika ke peserta didik dan dapat digunakan oleh guru untuk membantu menyelesaikan tugasnya dalam pembuatan soal, menulis buku, karya tulis, makalah, dan sebagainya.

Kegiatan pendampingan penerapan bahan ajar Student Centered berbasis informatika sebaiknya perlu diadakan pelatihan lagi untuk guru sekolah yang berbeda, perlu diberikan aplikasi lain dari Chem Office ke para guru untuk mengetahui tingkat inovasi yang dikembangkan guru dalam penerapan bahan ajar Student Centered berbasis informatika ke peserta didik, dan bagi guru IPA Terpadu dapat menjadikan aplikasi Chem Draw sebagai media guru untuk membuat bahan ajar student centered berbasis informatika.

\section{DAFTAR PUSTAKA}

Arysad, A. (2003). Media Pembelajaran. Jakarta : Rajawali Press.

Feiby, I. (2008). Solusi Peningkatan Kualitas Pendidikan. Jurnal Pendidikan vol 5 Januari-Juni. Diakses tanggal 1 Januari 2014.

Gunansyah, G., Rachmadiyanti, P., \& Subagiyo, F. X. M. (2018). Pelatihan Keterampilan Informasi Melalui
Pembuatan Media Literasi. Jurnal Publikasi Pendidikan, 8(1), 13-18.

Mulyasa, E. (2006). Kurikulum Yang Disempurnakan. Bandung: PT Remaja Rosdakarya.

Nurhaedah. (2012). IbM Pendekatan Kontekstual (Contextual Teaching and Learning/ CTL) dalam Pembelajaran Bagi Guru-Guru di SDN INPRES Bira 2 Bontoa Makassar. Publikasi, II(2), 153-159.

Jesse, G. (2012). ChemOffice. Inggris: PerkinElmer Inc. Diakses tanggal 1 Januari 2014. http://www.chambridgesoft.com. Wibowo. (2007). Manajemen Kinerja. Jakarta: Raja Grafindo Persada. 